\title{
PERAN OPINI AUDIT SEBAGAI PEMODERASI PENGARUH PROFITABILITAS, UKURAN PERUSAHAAN, KEPEMILIKAN INSTITUSIONAL, DAN KOMITE AUDIT TERHADAP KETEPATAN WAKTU PELAPORAN KEUANGAN
}

\begin{abstract}
THE ROLE OF AUDIT OPINION AS A MODERATOR OF THE AFFECT OF PROFITABILITY, FIRM SIZE, INSTITUTIONAL OWNERSHIP, AND AUDIT COMMITTEE TO THE TIMELINESS OF FINANCIAL REPORTING
\end{abstract}

\author{
Fadhli Azhari', Muhammad Nuryatno ${ }^{2}$ \\ ${ }^{12}$ Universitas Trisakti Jakarta \\ 1fadhliazhari06@gmail.com, ${ }^{2}$ nanotrisakti@gmail.com
}

\begin{abstract}
Abstrak
Penelitian ini bertujuan untuk mengetahui peran opini audit sebagai pemoderasi pengaruh profitabilitas, ukuran perusahaan, kepemilikan institusional, dan komite audit terhadap ketepatan waktu pelaporan keuangan pada perusahaan manufaktur yang terdaftar di Bursa Efek Indonesia periode tahun 2012 sampai dengan 2016. Metode pengambilan sampel yang digunakan adalah metode purposive sampling, sehingga diperoleh 96 perusahaan manufaktur. Teknik analisis data yang digunakan adalah menggunakan regresi logistik. Hasil pengujian hipotesis menunjukkan bahwa profitabilitas dan ukuran perusahaan berpengaruh positif terhadap ketepatan waktu pelaporan keuangan, sementara kepemilikan institusional dan komite audit tidak berpengaruh terhadap ketepatan waktu pelaporan keuangan. Opini audit tidak mampu memperkuat pengaruh profitabilitas, ukuran perusahaan, kepemilikan institusional, dan komite audit terhadap ketepatan waktu pelaporan keuangan.
\end{abstract}

Kata Kunci: Profitabilitas, Ukuran Perusahaan, Kepemilikan Institusional, Komite Audit, Opini Audit

\begin{abstract}
The purpose of this research is to find the role of audit opinion as a moderator of the affect of profitability, firm size, institutional ownership, and audit committee to the timeliness of financial reporting on manufacturing companies listed on the Indonesia Stock Exchange period 2012 to 2016. Sampling method used in this research is purposive sampling, so that obtained 96 sample manufacturing companies. Analysis data technique that used in this research is logistic regression. The hypothesis testing showed that profitability and firm size positively affects the timeliness of financial reporting, meanwhile institutional ownership and audit committee does not affect the timeliness of financial reporting. Audit opinion can not moderate the affect of profitability, firm size, institutional ownership, and audit committee to the timeliness of financial reporting.
\end{abstract}

Keywords: Profitability, Firm Size, Institutional Ownership, Audit Committee, Audit Opinion

\section{PENDAHULUAN}

Laporan keuangan merupakan gambaran kondisi suatu perusahaan karena memuat informasi-informasi yang dibutuhkan oleh pihak eksternal yang berkepentingan terhadap perusahaan. Laporan keuangan suatu perusahaan akan memiliki manfaat jika disampaikan secara akurat dan tepat waktu kepada para stakeholders sebagai pengambil keputusan. Hal ini menunjukkan betapa pentingnya ketepatan waktu pelaporan keuangan khususnya bagi perusahaan yang sudah go public, dimana diharuskan untuk menyusun laporan keuangan setiap periodenya.

Peraturan mengenai waktu pelaporan keuangan di Indonesia diatur pada oleh Bapepam-LK pada Peraturan Bapepam-LK Nomor X.K.2, Lampiran Keputusan Ketua Bapepam-LK Nomor KEP-346/BL/2011 tentang Penyampaian Laporan Keuangan Berkala Emiten atau Perusahaan 
Publik. Perubahan Bapepam-LK menjadi Otoritas Jasa Keuangan (OJK) sampai saat ini belum mempengaruhi peraturan yang berlaku sebelumnya, sehingga peraturan yang digunakan masih menggunakan aturan yang dikeluarkan oleh Bapepam-LK. Pada peraturan tersebut yang dimaksud adalah laporan keuangan tahunan dan laporan keuangan tengah tahunan. Sesuai dengan peraturan tersebut, laporan keuangan tahunan disertai dengan laporan akuntan dalam rangka audit laporan keuangan, harus disampaikan kepada Bapepam-LK (OJK) selambat-lambatnya pada akhir bulan ketiga setelah tanggal laporan keuangan. Kewajiban tentang pelaporan keuangan perusahaan yang terdaftar di pasar modal juga diatur dalam Undang-Undang No. 8 Tahun 1995 tentang Pasar Modal. Undang-undang tersebut menyebutkan semua perusahaan yang terdaftar di pasar modal wajib menyampaikan laporan keuangan berkala kepada Bapepam-LK (OJK) sesuai dengan batas waktu yang telah ditetapkan dalam Peraturan Bapepam-LK. Bagi perusahaan yang melanggar aturan tersebut akan dikenakan sanksi administrasi yang dapat berupa terguran tertulis, denda hingga penghentian sementara dari bursa.

Penyajian laporan keuangan secara tepat waktu merupakan aspek yang strategis untuk memperoleh keunggulan kompetitif dalam menunjang keberhasilan perusahaan. Banyak pihak yakin bahwa ketepatan waktu (timeliness) merupakan karakteristik penting bagi laporan keuangan. Informasi yang disajikan secara tidak tepat waktu akan mengurangi kemampuannya sebagai alat bantu prediksi bagi pemakainya dan informasi menjadi kurang relevan.

Seperti yang diberitakan neraca (www.neraca.co.id) untuk tahun buku 2012 terdapat 52 perusahaan yang belum melaporkan laporan keuangan tahunan auditannya. Tahun buku 2013 sebanyak 49 perusahaan terlambat menyampaikan laporan keuangan yang telah diaudit (www.kontan.co.id). Situs neraca juga memberitakan bahwa tahun buku 2014 sebanyak 52 perusahaan yang belum menyampaikan laporan keuangan audit. Bahkan menurut CNN Indonesia (www.cnnindonesia.com) PT Bursa Efek Indonesia mengganjar denda dan menghentikan sementara (suspensi) perdagangan saham 18 perusahaan karena belum menyampaikan laporan keuangan audit periode 31 Desember 2015. Menurut Jurnal Asia (www.jurnalasia.com) PT Bursa Efek Indonesia menghentikan sementara perdagangan efek (suspensi) terhadap 17 emiten karena belum menyampaikan laporan keuangan auditan periode 31 Desember 2016. Angka-angka tersebut menggambarkan bahwa ketepatan waktu penyampaian laporan keuangan masih menjadi kendala pada beberapa perusahaan publik di Indonesia.

Keterlambatan penyampaian laporan keuangan masih menjadi fenomena di Bursa Efek Indonesia. Hal ini dapat dilihat dari data tahun ke tahun dimana jumlah perusahaan yang terlambat menyampaikan laporan keuangan masih cukup banyak.

Berdasarkan dari hasil penelitian sebelumnya menunjukkan bahwa ketepatan waktu pelaporan keuangan dipengaruhi oleh profitabilitas (Dewi et al., 2016) senada dengan hasil penelitian dari Mahendra dan Putra (2014), Dewi dan Wirakusuma (2014), Sanjaya dan Wirawati (2016), Adebayo dan Adebiyi (2016) serta Pradipta dan Suryono (2017), ukuran perusahaan (Dewi et al., 2016) sejalan dengan penelitian Adebayo dan Adebiyi (2016), Sanjaya dan Wirawati (2016) serta Pradipta dan Suryono (2017), kepemilikan institusional (Mahendra dan Putra, 2014) sejalan dengan hasil penelitian Isani dan Ekowati (2015) dan Widyanjaya (2014), komite audit (Putri et al., 2015), likuiditas (Mahendra dan Putra 2014) senada dengan penelitian Dewi dan Wirakusuma (2014), opini audit (Kuswanto dan Manaf, 2015), ukuran KAP (Putri et al., 2015) sejalan dengan hasil penelitian Adebayo dan Adebiyi (2016), internal auditor (Putri et al., 2015), komisaris independen (Mahendra dan Putra, 2014), debt to equity ratio (Sanjaya dan Wirawati, 2016) sejalan dengan hasil penelitian Pradipta dan Suryono (2017), kualitas auditor (Pradipta dan Suryono, 2017), pergantian auditor (Sanjaya dan Wirawati, 2016), struktur kepemilikan (Sanjaya dan Wirawati, 2016).

Sedangkan untuk variabel yang tidak mempengaruhi ketepatan waktu adalah profitabilitas (Devi dan Suaryana, 2016), solvabilitas (Devi dan Suaryana, 2016), ukuran perusahaan (Mahendra dan Putra, 2014) sejalan dengan penelitian Dewi dan Hernawati (2015), Kuswanto dan Manaf (2015) serta Dewi dan Wirakusuma (2014), opini audit (Dewi dan Hernawati, 2015) sejalan dengan hasil penelitian Pradipta dan Suryono (2017), struktur kepemilikan (Dewi dan Hernawati 2015), komisaris independen (Dewi dan Wirakusuma, 2014), fee audit (Putri et al., 2015), Leverage (Adebayo dan Adebiyi, 2016). 
Berdasarkan penelitian di atas dapat dilihat bahwa masih ada beberapa variabel yang belum konsisten pengaruhnya yaitu pada variabel profitabilitas, ukuran perusahaan, opini audit, dan kepemilikan institusional. Maka dalam penelitian ini untuk menghindari perluasan masalah peneliti membatasi variabel yang akan diteliti hanya pada variabel profitabilitas, ukuran perusahaan, kepemilikan institusional, komite audit, dan opini audit sebagai variabel moderasi. Kebaruan dari penelitian ini adalah menggunakan variabel moderasi yaitu opini audit. Alasan peneliti menggunakan opini audit sebagai variabel moderasi karena opini audit diduga dapat memiliki pengaruh yang kuat dalam memoderasi hubungan beberapa variabel independen dengan variabel ketepatan waktu. Hasil penelitian Kuswanto dan Manaf (2015) menyatakan bahwa perusahaan yang mendapat opini audit dengan pendapat wajar tanpa pengecualian (unqualified opinion) dari auditor independen untuk laporan keuangannya cenderung akan lebih tepat waktu dalam penyampaian laporan keuangannya. Oleh karena itu, penelitian ini mengambil judul "Peran Opini Audit Sebagai Pemoderasi Pengaruh Profitabilitas, Ukuran Perusahaan, Kepemilikan Institusional, dan Komite Audit Terhadap Ketepatan Waktu Pelaporan Keuangan”.

\section{Pengaruh Profitabilitas Terhadap Ketepatan Waktu Pelaporan Keuangan}

Profitabilitas merupakan kemampuan perusahaan memperoleh laba dalam satu periode akuntansi setelah dibandingkan dengan total aset maupun modal sendiri (Sartono, 2014). Tingkat kemampuan perusahaan menghasilkan keuntungan yang dilaporkan, diperkirakan dapat mempengaruhi tepat atau tidaknya waktu penyajian laporan keuangan kepada publik. Hal ini diungkapkan oleh Carslaw dan Kaplan dalam Putra dan Ramantha (2015) dimana perusahaan yang mengalami kerugian operasional telah meminta auditornya untuk menjadwalkan pengauditan lebih lambat dari biasanya, ini berarti profitabilitas mempengaruhi ketepatan waktu pelaporan keuangan. Penelitian yang dilakukan oleh Dewi dan Jusia (2013), Mahendra dan Putra (2014), Dewi dan Wirakusuma (2014), Sanjaya dan Wirawati (2016), Adebayo dan Adebiyi (2016) serta Pradipta dan Suryono (2017) menunjukkan bahwa profitabilitas berpengaruh positif terhadap ketepatan waktu pelaporan keuangan.

$\mathrm{H}_{1}$ : Profitabilitas berpengaruh positif terhadap ketepatan waktu pelaporan keuangan.

\section{Pengaruh Ukuran Perusahaan Terhadap Ketepatan Waktu Pelaporan Keuangan}

Ukuran perusahaan diukur berdasarkan besar atau kecilnya perusahaan dengan melihat total aset atau total penjualan yang dimiliki oleh perusahaan. Adebayo dan Adebiyi (2016) mengatakan bahwa perusahaan besar memiliki kinerja, manajemen, dan teknologi yang lebih baik sehingga lebih tepat waktu dalam menyampaikan laporan keuangannya. Hasil penelitian Wirakusuma dan Cindrawati (2011) menunjukkan bahwa ukuran perusahaan memiliki pengaruh signifikan dan memiliki jenis hubungan negatif terhadap rentang waktu penyelesaian laporan keuangan auditan, dengan kata lain memiliki hubungan negatif dengan keterlambatan penyelesaian penyajian laporan keuangan atau memiliki hubungan positif terhadap ketepatan waktu pelaporan keuangan pada perusahaan yang listing di Bursa Efek Indonesia. Hal ini sejalan dengan penelitian Sanjaya dan Wirawati (2016), Adebayo dan Adebiyi (2016) serta Pradipta dan Suryono (2017) yang menunjukkan bahwa ukuran perusahaan berpengaruh positif terhadap ketepatan waktu pelaporan keuangan.

$\mathrm{H}_{2}$ : Ukuran perusahaan berpengaruh positif terhadap ketepatan waktu pelaporan keuangan.

\section{Pengaruh Kepemilikan Institusional Terhadap Ketepatan Waktu Pelaporan Keuangan}

Kepemilikan institusional diduga mampu mempengaruhi ketepatan waktu pelaporan keuangan tahunan. Cahan dan Zhang (2006) mengemukakan kepemilikan institusional sebagai persentase suatu perusahaan yang memiliki investment banking, mutual funds, dan pensiun, asuransi, bank, dan reksa dana. Keberadaan investor institusional dapat menunjukkan mekanisme corporate governance yang kuat sehingga mampu memberikan pengawasan terhadap manajemen perusahaan. Beberapa penelitian terdahulu telah dilakukan oleh para peneliti lain untuk menguji hubungan ketepatan waktu dengan kepemilikan institusional antara lain Kadir (2011), Mahendra dan Putra (2014), Widyanjaya (2014) serta Isani dan Ekowati (2015) menunjukkan bahwa kepemilikan institusional berpengaruh positif terhadap ketepatan waktu pelaporan keuangan. 
$\mathrm{H}_{3}$ : Kepemilikan institusional berpengaruh positif terhadap ketepatan waktu pelaporan keuangan.

\section{Pengaruh Komite Audit Terhadap Ketepatan Waktu Pelaporan Keuangan}

Dengan adanya anggota komite audit yang lebih dari satu, maka anggota komite audit akan berkolaborasi dan bekerja sama dalam hal peningkatan pengawasan terhadap aktivitas dewan direksi. Di Indonesia, pedoman pembentukan komite audit yang efektif menjelaskan bahwa anggota komite audit yang dimiliki oleh perusahaan sedikitnya terdiri dari 3 (tiga) orang, diketuai oleh komisaris independen dengan dua orang eksternal yang independen terhadap perusahaan serta menguasai dan memiliki latar belakang akuntansi dan keuangan (Komite Nasional Kebijakan Governance, 2006). Hal ini dikarenakan setiap anggota komite audit memiliki pengalaman dan pengetahuan terkait keuangan dan tata kelola perusahaan yang berbeda-beda. Penelitian yang dilakukan oleh Ika dan Ghazali (2012) serta Oussii dan Taktak (2018) menunjukkan komite audit berpengaruh positif terhadap ketepatan waktu pelaporan keuangan.

$\mathrm{H}_{4}$ : Komite audit berpengaruh positif terhadap ketepatan waktu pelaporan keuangan.

\section{Opini Audit Memoderasi Hubungan Antara Profitabilitas Terhadap Ketepatan Waktu Pelaporan Keuangan}

Perusahaan yang memiliki profitabilitas tinggi dapat dikatakan bahwa laporan keuangan perusahaan tersebut mengandung berita baik dan perusahaan yang mengalami berita baik cenderung menyerahkan laporan keuangannya tepat waktu (Dewi et al., 2016). Laporan keuangan yang mendapat opini audit wajar tanpa pengecualian (unqualified opinion) cenderung akan lebih tepat waktu dalam menyampaikan laporan keuangannya karena unqualified opinion merupakan good news dari auditor sehingga auditor tidak perlu melakukan prosedur tambahan dalam proses auditnya. Sebaliknya perusahaan akan cenderung tidak tepat waktu dalam menyampaikan laporan keuangannya apabila menerima opini selain unqualified opinion karena hal tersebut dianggap sebagai berita buruk (bad news). Profitabilitas yang tinggi serta opini audit unqualified opinion dapat menambah percaya diri perusahaan dalam menyampaikan laporan keuangan secara tepat waktu. Hal ini sesuai dengan penelitian yang dilakukan oleh Saputra dan Ramantha (2017) bahwa opini audit mampu memperkuat pengaruh positif profitabilitas terhadap ketepatan waktu pelaporan keuangan.

$\mathrm{H}_{5}$ : Opini audit memperkuat pengaruh positif profitabilitas terhadap ketepatan waktu pelaporan keuangan.

\section{Opini Audit Memoderasi Hubungan Antara Ukuran Perusahaan Terhadap Ketepatan Waktu Pelaporan Keuangan}

Sanjaya dan Wirawati (2016), Adebayo dan Adebiyi (2016), dan Ohaka dan Akani (2017) dalam penelitian mereka menemukan bahwa ukuran perusahaan secara signifikan mempunyai hubungan dengan ketepatan waktu penyampaian laporan keuangan. Ukuran (proksi) yang mereka gunakan untuk variabel ukuran perusahaan ini adalah dengan total aset. Bukti empiris yang ada menunjukkan bahwa perusahaan yang memiliki aset yang lebih besar melaporkan lebih cepat dibandingkan dengan perusahaan yang memiliki aset yang lebih kecil. Mereka beragumen bahwa perusahaan yang memiliki sumber daya (aset) yang besar memiliki lebih banyak sumber informasi, lebih banyak staf akuntansi, adanya pengawasan dari investor, regulator dan sorotan masyarakat, maka hal ini memungkinkan perusahaan untuk melaporkan keuangan auditanya lebih cepat ke publik.

Perusahaan besar yang laporan keuangannya mendapat opini unqualified opinion dari auditor independen akan cenderung menyampaikan laporan keuangannya tepat waktu karena perusahaan besar mendapat perhatian khusus dari para stakeholder. Hal ini sesuai dengan penelitian yang dilakukan oleh Turel (2010) bahwa perusahaan yang memperoleh opini selain unqualified opinion cenderung lebih lama untuk menyampaikan laporan keuangan dibandingkan perusahaan yang memperoleh opini unqualified opinion. Oleh karena itu, perusahaan besar saja tidak cukup menjamin akan menyampaikan laporan keuangan secara tepat waktu, melainkan perusahaan harus mendapat opini unqualified opinion agar semakin tepat waktu. 
$\mathrm{H}_{6}$ : Opini audit memperkuat pengaruh positif ukuran perusahaan terhadap ketepatan waktu pelaporan keuangan.

\section{Opini Audit Memoderasi Hubungan Antara Kepemilikan Institusional Terhadap Ketepatan Waktu Pelaporan Keuangan}

Menurut Machmud dan Djakman (2008) kepemilikan institusional merupakan pemegang saham terbesar sehingga memungkinkan untuk melakukan monitoring terhadap manajemen. Penyusunan laporan keuangan dipengaruhi oleh kepemilikan modal oleh pihak luar (Boediono, 2005). Hasil penelitian yang dilakukan oleh Harnida (2005) bahwa ada hubungan antara kepemilikan institusional dengan ketepatan waktu pelaporan keuangan, sedangkan hasil penelitian Mouna dan Anis (2013) menyatakan bahwa kepemilikan institusional tidak berpengaruh signifikan terhadap ketepatan waktu pelaporan keuangan.

Perusahaan yang dimiliki oleh institusi dan mendapat opini audit unqualified opinion dalam laporan keuangannya akan berusaha mempercepat penerbitan laporan keuangan, karena itu adalah berita baik buat pemegang saham. Selain itu, tekanan dari pemegang saham mayoritas membuat perusahaan menyampaikan laporan keuangan secara tepat waktu. Kuswanto dan Manaf (2015) menyatakan bahwa perusahaan yang memperoleh opini unqualified opinion dari auditor independen cenderung lebih tepat waktu dalam menyampaikan laporan keuangannya.

$\mathrm{H}_{7}$ : Opini audit memperkuat pengaruh positif kepemilikan institusional terhadap ketepatan waktu pelaporan keuangan.

\section{Opini Audit Memoderasi Hubungan Antara Komite Audit Terhadap Ketepatan Waktu Pelaporan Keuangan}

Komite audit merupakan komite bentukan dewan komisaris yang tanggung jawabnya kepada dewan komisaris. Komite audit juga membantu dewan komisaris untuk mengawasi proses mengolah informasi keuangan oleh manajemen untuk meningkatkan kualitas laporan keuangan (Ika dan Ghazali, 2012). Keefektifan komite audit akan meningkat seiring dengan bertambahnya ukuran komite audit, karena mereka memiliki sumber daya yang memadai untuk menghadapi masalah perusahaan (Oussii dan Taktak, 2018). Hal tersebut sejalan dengan Naimi et al. (2010) semakin banyak anggota komite audit dan semakin banyak pertemuan yang dilakukan akan meningkatkan ketepatan waktu pelaporan keuangan. Hasil penelitian yang dilakukan oleh Yadirichukwu dan Ebimobowei (2013) menyatakan bahwa ada pengaruh signifikan antara komite audit independen dan keahlian komite audit terhadap ketepatwaktuan pelaporan keuangan. Sejalan dengan penelitian yang dilakukan oleh Ika dan Ghazali (2012) bahwa komite audit memiliki pengaruh positif terhadap ketepatan waktu pelaporan keuangan.

Karena adanya pengawasan yang dilakukan oleh komite audit sehingga kualitas laporan keuangan menjadi meningkat dan opini yang diberikan oleh auditor independen atas laporan keuangan menjadi unqualified opinion. Unqualified opinion ini akan mempengaruhi sikap komite audit untuk mendorong manajemen dalam mempercepat penyampaian laporan keuangan agar tepat waktu. Menurut Kuswanto dan Manaf (2015) ketepatan waktu pelaporan keuangan berhubungan dengan pendapat auditor, dimana auditor yang memberikan pendapat unqualified opinion menjadikan berita baik bagi perusahaan sehingga akan tepat waktu dalam menyampaikan laporan keuangannya.

$\mathrm{H}_{8}$ : Opini audit memperkuat pengaruh positif komite audit terhadap ketepatan waktu pelaporan keuangan.

\section{METODE}

Penelitian ini adalah penelitian yang bersifat pengujian hipotesis karena dari hasil analisis data akan mencari tahu penyebab atau alasan yang mempengaruhi variabel independen terhadap variabel dependen. Data yang digunakan dalam penelitian ini adalah laporan keuangan perusahaan manufaktur yang terdaftar di Bursa Efek Indonesia periode 2012 - 2016. Strategi penelitian ini adalah menggunakan data sekunder dimana tersebut diperoleh dengan mengunduh pada website Bursa Efek Indonesia. 


\section{Definisi Operasional dan Pengukuran Variabel \\ Ketepatan Waktu}

Ketepatan waktu adalah tersedianya informasi bagi pembuat keputusan pada saat dibutuhkan sebelum informasi tersebut kehilangan kekuatan untuk mempengaruhi keputusan (Suwardjono, 2010:170). Ketepatan waktu diukur menggunakan variabel dummy. Kategori perusahaan yang menyampaikan laporan keuangan tepat waktu diberi nilai dummy 1 dan kategori perusahaan yang menyampaikan laporan keuangan tidak tepat waktu diberi nilai dummy 0 .

\section{Profitabilitas}

Profitabilitas merupakan salah satu indikator keberhasilan perusahaan untuk dapat menghasilkan laba sehingga semakin tinggi profitabilitas maka semakin tinggi kemampuan perusahaan untuk menghasilkan laba bagi perusahaannya (Kuswanto dan Manaf, 2015). Profitabilitas diukur melalui Return On Asset (ROA) yaitu dengan perbandingan laba bersih setelah pajak dengan rata-rata total aset.

$$
R O A=\frac{\text { Laba bersih setelah pajak }}{\text { Rata }- \text { rata total aset }}
$$

\section{Ukuran Perusahaan}

Ukuran perusahaan adalah suatu skala dimana dapat diklasifikasikan besar kecil perusahaan menurut berbagai cara, antara lain total nilai aset, total penjualan, kapitalisasi pasar, jumlah tenaga kerja dan sebagainya (Putra dan Thohiri, 2013).

$$
\text { Size }=\operatorname{Ln}(\text { Total Aset })
$$

\section{Kepemilikan Institusional}

Kepemilikan institusional adalah kepemilikan saham suatu perusahaan oleh institusi keuangan seperti perusahaan asuransi, bank, dana pensiun, dan investment banking (Siregar dan Utama, 2005).

$$
K I=\frac{\text { Jumlah saham institusi }}{\text { Jumlah saham beredar }} X 100 \%
$$

\section{Komite Audit}

Komite audit adalah komite yang dibentuk oleh dewan komisaris dan bertanggung jawab kepada dewan komisaris dalam membantu melaksanakan fungsi dewan komisaris, yang anggotanya diangkat dan diberhentikan oleh dewan komisaris, komite audit bertindak secara independen dalam melaksanakan tugas dan fungsi dewan komisaris (Putri et al., 2015). Dimensi yang dapat diukur dari komite audit adalah banyaknya jumlah anggota komite audit di perusahaan.

\section{Opini Audit}

Opini audit adalah pendapat auditor tentang laporan keuangan yang telah diauditnya (Islahuzzaman, 2012:292). Opini audit diukur menggunakan variabel dummy. Kategori perusahaan yang mendapat opini wajar tanpa pengecualian (unqualified opinion) dari auditor diberi nilai dummy 1 dan kategori perusahaan yang mendapat opini selain unqualified opinion diberi nilai dummy 0.

\section{Metode Pengumpulan Data}

Populasi dari penelitian ini adalah perusahaan manufaktur di Bursa Efek Indonesia periode 2012 - 2016. Jumlah perusahaan manufaktur pada periode tersebut sebanyak 133 perusahaan. Sampel diperoleh dengan menggunakan teknik purposive sampling yaitu memilih sampel dengan kriteria tertentu, sehingga sesuai dengan penelitian yang dirancang. 
Sesuai dengan jenis data yang diperlukan yaitu data sekunder dan teknik sampling yang digunakan yaitu purposive sampling, maka metode pengumpulan data didasarkan pada laporan keuangan yang dipublikasikan oleh Bursa Efek Indonesia melalui website (www.idx.co.id) periode 2012 - 2016. Data yang diperoleh kemudian diolah kembali dan disesuaikan dengan kebutuhan penelitian.

\section{Teknik Analisis Data}

Teknik analisis yang digunakan dalam penelitian ini menggunakan metode statistik deskriptif dan statistik inferensial. Statistik deskriptif bertujuan untuk mendeskripsikan atau menggambarkan data yang telah terkumpul. Statistik inferensial pada penelitian ini dilakukan dengan 2 tahap ( 2 model). Tahap pertama adalah menggunakan regresi logistik dengan menguji hubungan antara variabel independen dengan variabel dependen. Tahap kedua adalah menggunakan regresi logistik dengan menguji hubungan antara variabel independen dengan variabel dependen disertai dengan variabel moderasi.

Adapun model yang diajukan dalam penelitian ini adalah sebagai berikut:

$$
\text { Model 1: } \operatorname{Ln} \frac{T L}{1-T L}=\alpha+\beta_{1} X_{1}+\beta_{2} X_{2}+\beta_{3} X_{3}+\beta_{4} X_{4}+\varepsilon
$$

Model 2: $L n \frac{T L}{1-T L}=\alpha+\beta_{1} X_{1}+\beta_{2} X_{2}+\beta_{3} X_{3}+\beta_{4} X_{4}+\beta_{5} Z+\beta_{6} X_{1} Z+\beta_{7} X_{2} Z+\beta_{8} X_{3} Z+\beta_{9} X_{4} Z+\varepsilon$

Keterangan:

$$
\begin{array}{ll}
\operatorname{Ln} \frac{T L}{l-T L} & =\text { Dummy variabel ketepatan waktu }(1=\text { tepat waktu dan } 0=\text { tidak tepat waktu }) \\
\alpha & =\text { Konstanta regresi } \\
\beta & =\text { Koefisien regresi } \\
X_{1} & =\text { Profitabilitas (Return On Asset }) \\
X_{2} & =\text { Ukuran Perusahaan (Total Asset) } \\
X_{3} & =\text { Kepemilikan Institusional } \\
X_{4} & =\text { Komite Audit } \\
Z & =\text { Opini Audit } \\
\varepsilon & =\text { Residual }
\end{array}
$$

\section{HASIL DAN PEMBAHASAN \\ Deskripsi Data}

Data diperoleh dari laporan keuangan perusahaan manufaktur tahun 2012 sampai dengan tahun 2016 dapat diketahui bahwa jumlah perusahaan yang terdaftar di Bursa Efek Indonesia sebanyak 133 perusahaan. Dari jumlah tersebut, perusahaan yang dapat diambil sebagai sampel penelitian ini adalah sebanyak 96 perusahaan. Sumber data berasal dari website Bursa Efek Indonesia (www.idx.co.id) dan Indonesian Capital Market Electronic Library (ICaMEL). Penentuan jumlah sampel dilakukan dengan purposive sampling, dengan kriteria pengambilan sampel yang telah ditentukan.

\section{Deskripsi Sampel Penelitian}

Berdasarkan seleksi pemilihan sampel sesuai dengan kriteria yang telah ditentukan, maka dapat diperoleh 96 perusahaan setiap tahun yang memenuhi kriteria sampel, sehingga sampel yang digunakan dalam penelitian ini adalah sebanyak 480 (96x5) perusahaan yang dapat dilihat dalam tabel berikut: 
Tabel 1. Kriteria Pengambilan Sampel

\begin{tabular}{clc}
\hline No & \multicolumn{1}{c}{ Kriteria Pengambilan Sampel } & Jumlah \\
\hline 1 & $\begin{array}{l}\text { Perusahaan manufaktur yang terdaftar di Bursa Efek Indonesia } \\
\text { sejak periode 2012 - 2016 }\end{array}$ & 133 \\
2 & $\begin{array}{l}\text { Perusahaan manufaktur yang tidak menerbitkan laporan keuangan } \\
\text { audited dalam mata uang Rupiah per 31 Desember 2012 - } 31\end{array}$ & \\
$\begin{array}{l}\text { Desember 2016 } \\
\text { Perusahaan manufaktur yang pernah mengalami delisting selama } \\
\text { periode 2013 - 2016 }\end{array}$ & (6) \\
& $\begin{array}{l}\text { Perusahaan manufaktur yang pernah mengalami perubahan } \\
\text { kelompok usaha periode 2013 - 2016 }\end{array}$ & (2) \\
& $\quad$ Jumlah Sampel \\
\hline
\end{tabular}

Sumber: Data diolah, 2018

\section{Analisis Statistik Deskriptif}

Tabel 2. Analisis Statistik Deskriptif

\begin{tabular}{|c|c|c|c|c|c|}
\hline \multicolumn{6}{|c|}{ Descriptive Statistics } \\
\hline & $\mathbf{N}$ & Minimum & Maximum & Mean & $\begin{array}{c}\text { Std. } \\
\text { Deviation }\end{array}$ \\
\hline Profitabilitas (X1) & 480 & $-95,45$ & 40,38 & 4,9146 & 10,71103 \\
\hline Ukuran Perusahaan (X2) & 480 & 21,07 & 33,20 & 28,0587 & 1,68108 \\
\hline $\begin{array}{l}\text { Kepemilikan Institusional } \\
\text { (X3) }\end{array}$ & 480 & , 00 & 98,96 & 66,4658 & 23,83919 \\
\hline Komite Audit (X4) & 480 & 0 & 5 & 3,07 & ,470 \\
\hline Valid N (listwise) & 480 & & & & \\
\hline
\end{tabular}

Sumber: Data diolah, 2018

Nilai profitabilitas (ROA) terendah adalah -95,45 yang terjadi pada perusahaan PT Anugerah Kagum Karya Utama Tbk (AKKU) pada tahun 2015. Sedangkan nilai ROA tertinggi adalah 40,38 yang terjadi pada perusahaan PT Unilever Indonesia Tbk (UNVR) pada tahun 2012. Nilai ukuran perusahaan terendah adalah 21,07 yang terjadi pada perusahaan PT Anugerah Kagum Karya Utama Tbk (AKKU) pada tahun 2015. Sedangkan nilai ukuran perusahaan tertinggi adalah 33,20 yang terjadi pada perusahaan PT Astra Internasional Tbk (ASII) pada tahun 2016. Nilai kepemilikan institusional terendah adalah 0,00 persen yang terjadi pada perusahaan antara lain PT Semen Indonesia Tbk (SMGR) pada tahun 2012 - 2016, PT Intanwijaya Internasional Tbk (INCI) pada tahun 2012 - 2016, PT Kimia Farma Tbk (KAEF) pada tahun 2012 - 2016, PT Saranacentral Bajatama Tbk (BAJA) pada tahun 2012 - 2016, PT Indofarma Tbk (INAF) pada tahun 2012 2014, PT Siwani Makmur Tbk (SIMA) pada tahun 2015 - 2016, dan PT Jaya Pari Steel Tbk (JPRS) pada tahun 2016. Sedangkan nilai kepemilikan institusional tertinggi adalah 98,96 persen yang terjadi pada perusahaan PT Bentoel Internasional Investama Tbk (RMBA) pada tahun 2012 2014. Jumlah anggota komite audit tertinggi adalah 5 orang yaitu pada perusahaan PT Charoen Pokphand Indonesia Tbk (CPIN) pada tahun 2012 - 2016. Sedangkan jumlah anggota komite audit terendah adalah 0 orang (tidak ada) yaitu pada perusahaan PT Wismilak Inti Makmur Tbk (WIIM) pada tahun 2012. PT Wismilak Inti Makmur Tbk baru membentuk komite audit pada tahun 2013 sehingga pada tahun 2012 belum memiliki anggota komite audit.

\section{Analisis Statistik Inferensial}

1. Uji Kesesuaian Model

Adapun hasil pengujian Hosmer and Lemeshow Test untuk kedua tahap tersebut adalah:

Tahap 1 (Tanpa Moderasi): 
Tabel 3. Hosmer and Lemeshow Test

\begin{tabular}{cccc}
\hline Step & Chi-square & df & Sig. \\
\hline 1 & 14,660 & 8 &, 066 \\
\hline
\end{tabular}

Tahap 2 (Dengan Moderasi):

Tabel 4. Hosmer and Lemeshow Test

\begin{tabular}{cccc}
\hline Step & Chi-square & df & Sig. \\
\hline 1 & 12,029 & 8 &, 150 \\
\hline
\end{tabular}

Berdasarkan tabel diatas diketahui bahwa pada kedua tahap tersebut, nilai signifikansi uji lebih besar dari 0,05 yaitu 0,066 untuk tahap 1 dan 0,150 untuk tahap 2. Hal ini berarti untuk kedua tahap $\mathrm{H}_{0}$ diterima sehingga dapat disimpulkan bahwa model pada kedua tahap tersebut sudah mampu menjelaskan data. Oleh karena tidak ada perbedaan yang signifikan antara klasifikasi yang diprediksi dengan klasifikasi yang diamati maka dapat dilanjutkan ke tahap analisis selanjutnya.

2. Uji Simultan

Adapun hasil pengujian Omnibus Test of Model Coefficients untuk kedua tahap tersebut adalah:

Tahap 1 (Tanpa Moderasi):

Tabel 5. Omnibus Test of Model Coefficients

\begin{tabular}{llccc}
\hline & & Chi-square & df & Sig. \\
\hline Step 1 & Step & 42,096 & 4 &, 000 \\
& Block & 42,096 & 4 &, 000 \\
& Model & 42,096 & 4 &, 000 \\
\hline
\end{tabular}

Tahap 2 (Dengan Moderasi):

Tabel 6. Omnibus Test of Model Coefficients

\begin{tabular}{llccc}
\hline & & Chi-square & df & Sig. \\
\hline Step 1 & Step & 89,725 & 9 &, 000 \\
& Block & 89,725 & 9 &, 000 \\
& Model & 89,725 & 9 &, 000 \\
\hline
\end{tabular}

Berdasarkan tabel diatas diketahui bahwa pada kedua tahap tersebut nilai signifikansi uji lebih kecil dari 0,05 yaitu 0,000 untuk tahap 1 dan 0,000 untuk tahap 2. Hal ini berarti untuk kedua tahap $\mathrm{H}_{0}$ ditolak sehingga dapat disimpulkan bahwa minimal terdapat satu variabel yang berpengaruh signifikan terhadap ketepatan waktu pelaporan keuangan.

3. Uji Parsial

Adapun hasil pengujian Wald Test untuk kedua tahap tersebut adalah:

Tahap 1 (Tanpa Moderasi):

Tabel 7. Variables in the Equation

\begin{tabular}{llcc}
\hline & B & Sig. \\
\hline Step 1 $^{\mathrm{a}}$ & Profitabilitas (X1) &, 036 &, 004 \\
& Ukuran Perusahaan (X2) &, 361 &, 000 \\
& Kepemilikan Institusional &,- 001 &, 800 \\
& (X3) & & \\
& Komite Audit (X4) &,- 311 &, 215 \\
Constant & $-8,237$ &, 000 \\
\hline
\end{tabular}


Tahap 2 (Dengan Moderasi):

Tabel 8. Variables in the Equation

\begin{tabular}{llrr} 
& B & Sig. \\
\hline Step 1 $^{\mathrm{a}}$ & Profitabilitas (X1) &, 104 &, 002 \\
& Ukuran Perusahaan (X2) &, 853 &, 003 \\
Kepemilikan Institusional &,- 011 &, 285 \\
(X3) & & \\
Komite Audit (X4) &,- 924 &, 175 \\
Opini Audit (Z) & 15,22 &, 041 \\
& 1 & \\
X1*Z &,- 084 &, 021 \\
X2*Z &,- 594 &, 047 \\
X3*Z &, 012 &, 320 \\
X4*Z &, 788 &, 290 \\
Constant & - &, 003 \\
& 20,87 & \\
& 4 & \\
\hline
\end{tabular}

Berdasarkan kedua tabel di atas, dapat dilihat bahwa untuk tahap 1 maupun tahap 2 hanya variabel profitabilitas dan ukuran perusahaan yang berpengaruh terhadap ketepatan waktu pelaporan keuangan. Terlihat juga bahwa opini audit sebagai pemoderasi hanya mampu memperkuat pengaruh negatif profitabilitas dan ukuran perusahaan terhadap ketepatan waktu pelaporan keuangan. Sementara opini audit tidak mampu memperkuat pengaruh kepemilikan institusional dan komite audit terhadap ketepatan waktu pelaporan keuangan.

4. Uji Koefisien Determinasi

Adapun hasil output SPSS untuk koefisien determinasi adalah sebagai berikut:

Tahap 1 (Tanpa Moderasi):

Tabel 9. Uji Koefisien Determinasi

\begin{tabular}{cccc}
\hline Step & $\begin{array}{c}-2 \text { Log } \\
\text { likelihood }\end{array}$ & $\begin{array}{c}\text { Cox \& Snell } \\
\text { R Square }\end{array}$ & $\begin{array}{c}\text { Nagelkerke } \\
\text { R Square }\end{array}$ \\
\hline 1 & $528,269^{\mathrm{a}}$ &, 084 &, 121 \\
\hline
\end{tabular}

Nilai Nagelkerke $R$ Square sebesar 0,121 berarti ketepatan waktu pelaporan keuangan mampu dijelaskan oleh variabel independen sebesar 12,1 persen dan sisanya sebesar 87,9 persen dipengaruhi oleh variabel lain di luar model.

Tahap 2 (Dengan Moderasi):

Tabel 10. Uji Koefisien Determinasi

\begin{tabular}{lccc}
\hline & $\begin{array}{c}-2 \text { Log } \\
\text { Step } \\
\text { likelihood }\end{array}$ & $\begin{array}{c}\text { Cox \& Snell } \\
\text { R Square }\end{array}$ & $\begin{array}{c}\text { Nagelkerke } \\
\text { R Square }\end{array}$ \\
\hline 1 & $480,640^{\mathrm{a}}$ &, 170 &, 245 \\
\hline
\end{tabular}

Nilai Nagelkerke $R$ Square dengan moderasi sebesar 0,245 berarti ketepatan waktu pelaporan keuangan mampu dijelaskan oleh variabel independen yang dimoderasi sebesar 24,5 persen dan sisanya sebesar 75,5 persen dipengaruhi oleh variabel lain di luar model.

5. Uji Tingkat Ketepatan Prediksi Model

Hasil uji tingkat ketepatan prediksi model dapat ditunjukkan pada tabel berikut: 
Model 1 (Tanpa Moderasi):

Tabel 11. Classification Table

\begin{tabular}{llcccc}
\hline & & & \multicolumn{3}{c}{ Predicted } \\
\cline { 3 - 4 } & & Observed & \multicolumn{2}{c}{ Ketepatan Waktu } & \\
\cline { 3 - 5 } & & $\begin{array}{c}\text { Tidak } \\
\text { Tepat }\end{array}$ & Tepat & Percentage \\
& & Waktu & Waktu & \\
\hline Step & Ketepatan & Tidak Tepat Waktu & 14 & 121 & 10,4 \\
1 & Waktu (Y) & Tepat Waktu & 8 & 337 & 97,7 \\
& Overall Percentage & & & 73,1 \\
\hline
\end{tabular}

Terlihat pada classification table bahwa model tahap 1 mampu memprediksi dengan tingkat akurasi sebesar 73,1 persen, merupakan tingkat akurasi yang cukup baik dalam pengklasifikasian data.

Model 2 (Dengan Moderasi):

Tabel 12. Classification Table

\begin{tabular}{|c|c|c|c|c|c|}
\hline & \multirow[b]{3}{*}{ Observed } & \multirow{2}{*}{\multicolumn{3}{|c|}{$\frac{\text { Predicted }}{\text { Ketepatan Waktu (Y) }}$}} \\
\hline & & & & & \\
\hline & & & $\begin{array}{l}\text { Tidak } \\
\text { Tepat } \\
\text { Waktu }\end{array}$ & $\begin{array}{c}\text { Tepat } \\
\text { Waktu }\end{array}$ & $\begin{array}{l}\text { Percentage } \\
\text { Correct }\end{array}$ \\
\hline \multirow[t]{3}{*}{ Step } & Ketepatan & Tidak Tepat Waktu & 41 & 94 & 30,4 \\
\hline & Waktu (Y) & Tepat Waktu & 14 & 331 & 95,9 \\
\hline & \multicolumn{2}{|c|}{ Overall Percentage } & & & 77,5 \\
\hline
\end{tabular}

Terlihat pada classification table bahwa model tahap 2 mampu memprediksi dengan tingkat akurasi sebesar 77,5 persen, merupakan tingkat akurasi yang cukup baik dalam pengklasifikasian data.

6. Interpretasi Model

Model regresi logistik dapat dibentuk dengan melihat pada nilai estimasi parameter dalam Variables in the Equation.

Model 1 (Tanpa Moderasi):

$$
\text { Ln } \frac{T L}{1-T L}=-8,237+0,036 \mathrm{X}_{1}+0,361 \mathrm{X}_{2}-0,001 \mathrm{X}_{3}-0,311 \mathrm{X}_{4}+\varepsilon
$$

Model 2 (Dengan Moderasi):

$$
\begin{gathered}
\text { Ln } \frac{T L}{1-T L}=-20,874+0,104 \mathrm{X}_{1}+0,853 \mathrm{X}_{2}-0,011 \mathrm{X}_{3}-0,924 \mathrm{X}_{4}+15,221 . \mathrm{Z}- \\
0,084 \mathrm{X}_{1} * \mathrm{Z}-0,594 \mathrm{X}_{2} * \mathrm{Z}+0,012 \mathrm{X}_{3} * \mathrm{Z}+0,788 \mathrm{X}_{4} * \mathrm{Z}+\varepsilon
\end{gathered}
$$

\section{Pembahasan Hasil Penelitian}

1. Profitabilitas Berpengaruh Positif Terhadap Ketepatan Waktu Pelaporan Keuangan

Hipotesis pertama yang diajukan dalam penelitian ini adalah profitabilitas berpengaruh positif terhadap ketepatan waktu pelaporan keuangan. Berdasarkan hasil pengujian hipotesis untuk kedua model tersebut dilihat pada tabel model 1 dan model 2 di atas dapat diketahui bahwa profitabilitas memiliki nilai koefisien regresi positif sebesar 0,036 dengan nilai signifikansi 0,004< 
0,05 pada pengujian tahap 1. Sedangkan pengujian tahap 2 koefisien regresi sebesar 0,104 dengan nilai signifikansi $0,002<0,05$. Sehingga dapat disimpulkan bahwa profitabilitas berpengaruh positif terhadap ketepatan waktu pelaporan keuangan. Kesimpulan dari hasil pengujian regresi logistik untuk hipotesis pertama terhadap variabel profitabilitas (ROA), yaitu secara empiris menunjukkan bahwa profitabilitas (ROA) berpengaruh positif terhadap ketepatan waktu pelaporan keuangan. Semakin tinggi tingkat profitabilitas maka semakin tinggi kecenderungan untuk menyampaikan laporan keuangan secara tepat waktu. Hasil penelitian ini sejalan dengan penelitian Dewi dan Jusia (2013), Mahendra dan Putra (2014), Dewi dan Wirakusuma (2014), Sanjaya dan Wirawati (2016), Adebayo dan Adebiyi (2016) serta Pradipta dan Suryono (2017) yang menunjukkan bahwa profitabilitas berpengaruh positif terhadap ketepatan waktu pelaporan keuangan.

\section{Ukuran Perusahaan Berpengaruh Positif Terhadap Ketepatan Waktu Pelaporan Keuangan}

Hipotesis kedua yang diajukan dalam penelitian ini adalah ukuran perusahaan berpengaruh positif terhadap ketepatan waktu pelaporan keuangan. Berdasarkan hasil pengujian hipotesis untuk kedua model tersebut dilihat pada tabel model 1 dan model 2 di atas dapat diketahui bahwa ukuran perusahaan memiliki nilai koefisien regresi positif sebesar 0,361 dengan nilai signifikansi $0,000<$ 0,05 pada pengujian tahap 1. Sedangkan pengujian tahap 2 koefisien regresi sebesar 0,853 dengan nilai signifikansi $0,003<0,05$. Sehingga dapat disimpulkan bahwa ukuran perusahaan berpengaruh positif terhadap ketepatan waktu pelaporan keuangan. Hasil pengujian hipotesis membuktikan bahwa ukuran perusahaan berpengaruh positif terhadap ketepatan waktu pelaporan keuangan. Perusahaan yang memiliki sumber daya (aset) yang besar memiliki lebih banyak sumber informasi, lebih banyak staf akuntansi dan sistem informasi yang lebih canggih, memiliki sistem pengendalian internal yang kuat, adanya pengawasan dari investor, regulator, dan sorotan masyarakat. Hal ini memungkinkan perusahaan untuk melaporkan laporan keuangan auditannya lebih cepat ke publik. Hasil penelitian ini sejalan dengan penelitian yang dilakukan oleh Sanjaya dan Wirawati (2016), Adebayo dan Adebiyi (2016) serta Pradipta dan Suryono (2017) yang menunjukan bahwa ukuran perusahaan berpengaruh positif terhadap ketepatan waktu pelaporan keuangan.

\section{Kepemilikan Institusional Berpengaruh Positif Terhadap Ketepatan Waktu Pelaporan Keuangan}

Hipotesis ketiga yang diajukan dalam penelitian ini adalah kepemilikan institusional berpengaruh positif terhadap ketepatan waktu pelaporan keuangan. Berdasarkan hasil pengujian hipotesis untuk kedua model tersebut dilihat pada tabel model 1 dan model 2 di atas dapat diketahui bahwa kepemilikan institusional memiliki nilai koefisien regresi negatif sebesar $-0,001$ dengan nilai signifikansi 0,800 >0,05 pada pengujian tahap 1. Sedangkan pengujian tahap 2 koefisien regresi sebesar $-0,011$ dengan nilai signifikansi $0,285>0,05$. Sehingga dapat disimpulkan bahwa kepemilikan institusional tidak berpengaruh positif terhadap ketepatan waktu pelaporan keuangan. Kepemilikan institusional tidak berpengaruh terhadap ketepatan waktu pelaporan keuangan. Kesimpulan dari hasil pengujian regresi logistik untuk hipotesis ketiga yaitu variabel kepemilikan institusional secara empiris menunjukkan bahwa belum cukup bukti menyatakan kepemilikan institusional berpengaruh terhadap ketepatan waktu pelaporan keuangan. Tidak berpengaruhnya kepemilikan institusional terhadap ketepatan waktu pelaporan keuangan diduga karena kurangnya pengawasan dari pihak institusi selaku pemegang saham dan pihak institusi lebih mementingkan angka dalam laporan keuangan terutama laba (profit) ketimbang waktu penyampaian laporan keuangan. Hasil penelitian ini sesuai dengan penelitian yang dilakukan oleh Putra dan Ramantha (2015) serta Dwiyani et al. (2017) yang menyatakan bahwa kepemilikan institusional tidak berpengaruh terhadap ketepatan waktu pelaporan keuangan.

\section{Komite Audit Berpengaruh Positif Terhadap Ketepatan Waktu Pelaporan Keuangan}

Hipotesis keempat yang diajukan dalam penelitian ini adalah komite audit berpengaruh positif terhadap ketepatan waktu pelaporan keuangan. Berdasarkan hasil pengujian hipotesis untuk kedua model tersebut dilihat pada tabel model 1 dan model 2 di atas dapat diketahui bahwa komite audit memiliki nilai koefisien regresi negatif sebesar $-0,311$ dengan nilai signifikansi 0,215 >0,05 pada pengujian tahap 1. Sedangkan pengujian tahap 2 koefisien regresi sebesar $-0,924$ dengan nilai 
signifikansi $0,175>0,05$. Sehingga dapat disimpulkan bahwa komite audit tidak berpengaruh positif terhadap ketepatan waktu pelaporan keuangan. Komite audit tidak berpengaruh terhadap ketepatan waktu pelaporan keuangan. Kesimpulan dari hasil pengujian regresi logistik untuk hipotesis keempat yaitu variabel komite audit secara empiris menunjukkan bahwa belum cukup bukti menyatakan komite audit berpengaruh terhadap ketepatan waktu pelaporan keuangan. Hasil penelitian ini menggambarkan bahwa banyaknya anggota komite audit tidak berpengaruh terhadap ketepatan waktu pelaporan keuangan. Hasil ini konsisten dengan penelitian Putra dan Ramantha (2015) yang memberikan hasil bahwa kurang efektifnya komite audit dalam mendorong perusahaan untuk menyerahkan laporan keuangan tepat waktu. Penelitian ini juga sejalan dengan penelitian Widyaswari dan Suardana (2014) dan Putri et al. (2015) yang tidak berhasil membuktikan pengaruh komite audit terhadap ketepatan waktu pelaporan keuangan. Penelitian tersebut menunjukkan bahwa ukuran komite audit bukan faktor penentu efektivitas komite audit. Semakin besar ukuran anggota komite audit akan mengakibatkan sulitnya membentuk jaringan komunikasi dan koordinasi yang baik antar anggota komite audit. Selain itu, akan cukup sulit untuk mengambil keputusan dari keterlibatan anggota komite audit yang berjumlah besar.

\section{Opini Audit Memperkuat Pengaruh Positif Profitabilitas Terhadap Ketepatan Waktu Pelaporan Keuangan}

Hipotesis kelima yang diajukan dalam penelitian ini adalah opini audit memperkuat pengaruh positif profitabilitas terhadap ketepatan waktu pelaporan keuangan. Berdasarkan hasil pengujian hipotesis pada tahap 2 dapat dilihat bahwa opini audit yang memperkuat pengaruh positif profitabilitas terhadap ketepatan waktu pelaporan keuangan memiliki tingkat signifikansi sebesar $0,021<0,05$ namun dengan nilai koefisien regresi negatif sebesar $-0,084$ yang berlawanan dengan hipotesis. Sehingga dapat disimpulkan bahwa opini audit tidak mampu memperkuat pengaruh positif profitabilitas terhadap ketepatan waktu pelaporan keuangan. Opini audit tidak mampu memperkuat pengaruh positif profitabilitas terhadap ketepatan waktu pelaporan keuangan. Kesimpulan hasil pengujian regresi logistik untuk hipotesis kelima belum cukup bukti menyatakan bahwa opini audit memperkuat pengaruh positif profitabilitas terhadap ketepatan waktu pelaporan keuangan. Hal ini konsisten dengan penelitian yang dilakukan oleh Mellyana dan Astuti (2005) yang menyatakan bahwa opini audit tidak mampu memperkuat interaksi antara profitabilitas perusahaan dan ketepatan waktu pelaporan keuangan. Tidak semua perusahaan menyampaikan laporan keuangan yang telah diaudit tepat waktu meskipun opini audit yang didapat itu wajar tanpa pengecualian (unqualified opinion). Hal ini diduga terjadi akibat ada faktor lain yang menyebabkan laporan keuangan disampaikan tidak tepat waktu seperti faktor audit delay.

\section{Opini Audit Memperkuat Pengaruh Positif Ukuran Perusahaan Terhadap Ketepatan Waktu Pelaporan Keuangan}

Hipotesis keenam yang diajukan dalam penelitian ini adalah opini audit memperkuat pengaruh positif ukuran perusahaan terhadap ketepatan waktu pelaporan keuangan. Berdasarkan hasil pengujian hipotesis pada tahap 2 dapat dilihat bahwa opini audit yang memperkuat pengaruh positif ukuran perusahaan terhadap ketepatan waktu pelaporan keuangan memiliki tingkat signifikansi sebesar 0,047 $<0,05$ namun dengan nilai koefisien regresi negatif sebesar -0,594 yang berlawanan dengan hipotesis. Sehingga dapat disimpulkan bahwa opini audit tidak mampu memperkuat pengaruh positif ukuran perusahaan terhadap ketepatan waktu pelaporan keuangan. Opini audit tidak mampu memperkuat pengaruh positif ukuran perusahaan terhadap ketepatan waktu pelaporan keuangan. Kesimpulan hasil pengujian regresi logistik untuk hipotesis keenam belum cukup bukti menyatakan bahwa opini audit memperkuat pengaruh positif ukuran perusahaan terhadap ketepatan waktu pelaporan keuangan. Hasil penelitian ini sejalan dengan penelitian yang dilakukan oleh Saputra dan Ramantha (2017) yang menyebutkan bahwa opini audit tidak mampu memperkuat pengaruh ukuran perusahaan terhadap ketepatan waktu pelaporan keuangan. Dalam penelitian tersebut disebutkan bahwa terdapat kemungkinan opini audit bukan satu-satunya faktor yang menjadi pertimbangan perusahaan dalam menyampaikan laporan keuangan, dimana auditor dalam memberikan opininya tidak didasarkan pada ukuran perusahaan tersebut, melainkan berdasarkan kewajaran laporan keuangan yang dihasilkan perusahaan. Penelitian yang dilakukan 
oleh Turel (2010) menyatakan bahwa perusahaan yang memperoleh opini audit selain wajar tanpa pengecualian cenderung lebih lama untuk menyampaikan laporan keuangan dibandingkan perusahaan yang memperoleh opini wajar tanpa pengecualian. Oleh karena itu, semakin besar perusahaan belum cukup menjamin perusahaan menyampaikan laporan keuangan secara tepat waktu, melainkan perusahaan harus memperoleh opini wajar tanpa pengecualian agar semakin tepat waktu dalam menyampaikan laporan keuangan.

7. Opini Audit Memperkuat Pengaruh Positif Kepemilikan Institusional Terhadap Ketepatan Waktu Pelaporan Keuangan

Hipotesis ketujuh yang diajukan dalam penelitian ini adalah opini audit memperkuat pengaruh positif kepemilikan institusional terhadap ketepatan waktu pelaporan keuangan. Berdasarkan hasil pengujian hipotesis pada tahap 2 dapat dilihat bahwa opini audit yang memperkuat pengaruh positif kepemilikan institusional terhadap ketepatan waktu pelaporan keuangan memiliki tingkat signifikansi sebesar 0,320>0,05 dengan nilai koefisien regresi positif sebesar 0,012. Sehingga dapat disimpulkan bahwa opini audit tidak mampu memperkuat pengaruh positif kepemilikan institusional terhadap ketepatan waktu pelaporan keuangan. Opini audit tidak mampu memperkuat pengaruh positif kepemilikan institusional terhadap ketepatan waktu pelaporan keuangan. Kesimpulan hasil pengujian regresi logistik untuk hipotesis ketujuh belum cukup bukti menyatakan bahwa opini audit memperkuat pengaruh positif kepemilikan institusional terhadap ketepatan waktu pelaporan keuangan. Penelitian ini sejalan dengan penelitian Mouna dan Anis (2013) yang menyatakan bahwa kepemilikan institusional tidak berpengaruh terhadap ketepatan waktu pelaporan keuangan. Tidak mampunya opini audit dalam memperkuat pengaruh kepemilikan institusional terhadap ketepatan waktu pelaporan keuangan, dikarenakan opini audit hanya menilai kewajaran laporan keuangan bukan faktor utama dalam penyampaian laporan keuangan. Dalam memberikan opini audit, akuntan publik tidak mendasarkan kewajaran laporan keuangan kepada persentase kepemilikan institusional. Selain itu, ditemukan juga beberapa perusahaan yang memiliki persentase kepemilikan institusional mencapai 98 persen dan memperoleh opini wajar tanpa pengecualian tetapi tidak menyampaikan laporan keuangan tepat waktu. Hal ini membuktikan bahwa besarnya persentase kepemilikan institusional dan opini wajar tanpa pengecualian bukan jaminan perusahaan tersebut akan menyampaikan laporan keuangan tepat waktu.

\section{Opini Audit Memperkuat Pengaruh Positif Komite Audit Terhadap Ketepatan Waktu Pelaporan} Keuangan

Hipotesis kedelapan yang diajukan dalam penelitian ini adalah opini audit memperkuat pengaruh positif komite audit terhadap ketepatan waktu pelaporan keuangan. Berdasarkan hasil pengujian hipotesis pada tahap 2 dapat dilihat bahwa opini audit yang memperkuat pengaruh positif komite audit terhadap ketepatan waktu pelaporan keuangan memiliki tingkat signifikansi sebesar $0,290>0,05$ dengan nilai koefisien regresi positif sebesar 0,788. Sehingga dapat disimpulkan bahwa opini audit tidak mampu memperkuat pengaruh positif komite audit terhadap ketepatan waktu pelaporan keuangan. Opini audit tidak mampu memperkuat pengaruh positif komite audit terhadap ketepatan waktu pelaporan keuangan. Kesimpulan hasil pengujian regresi logistik untuk hipotesis kedelapan belum cukup bukti menyatakan bahwa opini audit memperkuat pengaruh positif komite audit terhadap ketepatan waktu pelaporan keuangan. Berdasarkan hasil penelitian ini ditemukan bahwa semakin banyak anggota komite audit dan mendapat opini wajar tanpa pengecualian justru cenderung untuk tidak menyampaikan laporan keuangan secara tepat waktu. Bahkan terdapat beberapa perusahaan yang memiliki jumlah anggota komite audit 4 orang, dimana jumlah tersebut diatas standar minimal yang dipersyaratkan oleh Otoritas Jasa Keuangan (OJK) yaitu 3 orang. Hal ini tidak sesuai dengan konsep teori yang menyebutkan bahwa keefektifan komite audit akan meningkat seiring dengan bertambahnya ukuran komite audit karena memiliki sumber daya yang memadai untuk menghadapi masalah perusahaan (Oussii dan Taktak, 2018). Hasil penelitian ini sejalan dengan penelitian Putra dan Ramantha (2015) yang menunjukkan bahwa komite audit tidak berpengaruh terhadap ketepatan waktu pelaporan keuangan. Tidak mampunya opini audit dalam memoderasi pengaruh komite audit terhadap ketepatan waktu 
pelaporan keuangan diduga karena opini audit yang diberikan oleh akuntan publik hanya berdasarkan pada kewajaran atas laporan keuangan, bukan atas keefektifan fungsi dan jumlah anggota komite audit dalam mengawasi manajemen dalam hal pelaporan keuangan.

\section{KESIMPULAN} berikut:

Berdasarkan analisis data dan pembahasan hasil penelitian, maka dapat disimpulkan sebagai

1. Profitabilitas berpengaruh positif terhadap ketepatan waktu pelaporan keuangan dan artinya hipotesis pertama $\left(\mathrm{H}_{1}\right)$ diterima.

2. Ukuran perusahaan berpengaruh positif terhadap ketepatan waktu pelaporan keuangan dan artinya hipotesis kedua $\left(\mathrm{H}_{2}\right)$ diterima.

3. Kepemilikan institusional tidak berpengaruh terhadap ketepatan waktu pelaporan keuangan dan artinya hipotesis ketiga $\left(\mathrm{H}_{3}\right)$ ditolak.

4. Komite audit tidak berpengaruh terhadap ketepatan waktu pelaporan keuangan dan artinya hipotesis keempat $\left(\mathrm{H}_{4}\right)$ ditolak.

5. Opini audit tidak mampu memperkuat pengaruh positif profitabilitas terhadap ketepatan waktu pelaporan keuangan dan artinya hipotesis kelima $\left(\mathrm{H}_{5}\right)$ ditolak.

6. Opini audit tidak mampu memperkuat pengaruh positif ukuran perusahaan terhadap ketepatan waktu pelaporan keuangan dan artinya hipotesis keenam $\left(\mathrm{H}_{6}\right)$ ditolak.

7. Opini audit tidak mampu memperkuat pengaruh positif kepemilikan institusional terhadap ketepatan waktu pelaporan keuangan dan artinya hipotesis ketujuh $\left(\mathrm{H}_{7}\right)$ ditolak.

8. Opini audit tidak mampu memperkuat pengaruh positif komite audit terhadap ketepatan waktu pelaporan keuangan dan artinya hipotesis kedelapan $\left(\mathrm{H}_{8}\right)$ ditolak.

\section{DAFTAR PUSTAKA}

Adebayo, P. A. and W. K. Adebiyi. 2016. Effect of Firm Characteristics on The Timeliness of Corporate Financial Reporting: Evidence from Nigerian Deposit Money Banks. International Journal of Economics, Commerce and Management, Vol. IV No. 3: 369-381.

Al Daoud, K.A., K. N. I. K Ismail and N. A. Lode. 2014. The Timeliness of Financial Reporting among Jordanian Companies: Do Company and Board Characteristic, and Audit Opinion Matter?. Asian Social Science, Vol. 10 No. 13: 191-201.

Cahan, S. F. and W. Zhang. 2006. After Enron: Auditor Conservatism and Ex-Andersen Clients. The Accounting Review, Vol. 81 No. 1: 49-82.

Devi, N. L. L. S dan I. G. N. A. Suaryana. 2016. Pengaruh Profitabilitas dan Solvabilitas Terhadap Ketepatan Waktu dengan Reputasi Kantor Akuntan Publik sebagai Pemoderasi. E-Jurnal Akuntansi Universitas Udayana, Vol. 17 No. 1: 395-425.

Dewi, S. P. dan Jusia. 2013. Faktor-Faktor yang Mempengaruhi Ketepatan Waktu Penyampaian Laporan Keuangan pada Perusahaan Real Estate dan Property yang Terdaftar di BEI. Jurnal Akuntansi, Vol. XVII No. 3: 368-384.

Dewi, I. G. A. R. P dan M. G. Wirakusuma. 2014. Fenomena Ketepatwaktuan Informasi Keuangan dan Faktor yang Mempengaruhi di Bursa Efek Indonesia. E-Jurnal Akuntansi Universitas Udayana, Vol. 8 No. 1: 171-186.

Dewi, M. S. dan E. Hernawati. 2015. Pengaruh Opini Audit, Struktur Kepemilikan, dan Ukuran Perusahaan Terhadap Ketepatan Waktu Penyampaian Laporan Keuangan. Proceeding Seminar Nasional \& Call for Papers (SCA 5), Vol. 5 No. 1: 1-12.

Dewi, I. G. A. R. P., I. K. Yadnyana, dan I. P. Sudana. 2016. Pengaruh Profitabilitas dan Ukuran Perusahaan Terhadap Ketepatwaktuan Penyampaian Laporan Keuangan dan Implikasinya 
pada Earnings Response Coefficient. E-Jurnal Ekonomi dan Bisnis Universitas Udayana, Vol. 5 No. 9: 3031-3056.

Dwiyani, S. A., I. D. N. Badera, dan I. P. Sudana. 2017. Faktor-Faktor Yang Mempengaruhi Ketepatwaktuan Penyajian Laporan Keuangan. E-Jurnal Ekonomi dan Bisnis Universitas Udayana, Vol. 6 No. 4: 1451-1480.

Gulec, O. F. 2017. Timeliness of Corporate Reporting in Developing Economic: Evidence from Turkey. Accounting and Management Information Systems, Vol. 16 No. 3: 219-239.

Ika, S. R. and N. A. M. Ghazali. 2012. Audit Commitee Effectiveness and Timeliness of Reporting: Indonesian Evidence. Managerial Auditing Journal, Vol. 27 No. 4: 403-424.

Isani, E. S. dan W. H. Ekowati. 2015. Pengaruh Kepemilikan Institusional dan Manajemen Laba Terhadap Ketepatan Waktu Pelaporan Keuangan (Studi pada Perusahaan Manufaktur di Bursa Efek Indonesia Periode 2011 - 2013). Jurnal Ilmiah Mahasiswa FEB Universitas Brawijaya, Vol. 4 No. 1: 1-18.

Kadir, Abdul. 2011. Faktor-Faktor yang Berpengaruh Terhadap Ketepatan Waktu Pelaporan Keuangan Studi Empiris pada Perusahaan Manufaktur di Bursa Efek Jakarta. Jurnal Manajemen dan Akuntansi, Vol. 12 No. 1: 1-12.

Kuswanto, H. dan S. Manaf. 2015. Faktor-Faktor yang Mempengaruhi Ketepatan Waktu Penyampaian Laporan Keuangan ke Publik (Studi Empiris pada Perusahaan Manufaktur yang Terdaftar di Bursa Efek Indonesia Periode 2010 - 2013). Jurnal Ekonomi Manajemen Akuntansi, Vol. 22 No. 38: 1-18.

Machmud, N. dan C. D. Djakman. 2008. Pengaruh Struktur Kepemilikan terhadap Luas Pengungkapan Tanggung Jawab Sosial (CSR Disclosure) pada Laporan Tahunan Perusahaan: Studi Empiris pada Perusahaan Publik yang Tercatat di Bursa Efek Indonesia tahun 2006. SNA XI Pontianak.

Mahendra, I. B. K. Y dan I. N. W. A. Putra. 2014. Pengaruh Komisaris Independen, Kepemilikan Institusional, Profitabilitas, Likuiditas, dan Ukuran Perusahaan Terhadap Ketepatwaktuan. E-Journal Akuntansi Universitas Udayana, Vol. 9 No. 1: 180-199.

McGee, R. W. and X. Yuan. 2009. Corporate Governance and The Timeliness of Financial Reporting: An Empirical Study of The People's Republic of China. International Journal of Business, Accounting, and Finance, Vol. 3 No. 1: 19-27.

Mellyana, D. dan C. D. Astuti. 2005. Pengaruh Profitabilitas Perusahaan Terhadap Ketepatan Waktu Pelaporan Laporan Keuangan. Jurnal Akuntansi, Vol. 5 No. 3: 337-358.

Mouna, A. and J. Anis. 2013. Financial Reporting Delay and Investors Behavior: Evidence from Tunisia. International Journal of Management and Business Research, Vol. 3 No. 1: 57-67.

Naimi, M. N, R. Shafie and W. N. Hussin. 2010. Corporate Governance and Audit Report Lag in Malaysia. Asian Academy of Management Journal of Accounting and Finance, Vol. 6 No. 2: 57-84.

Ohaka, J. and N. F. Akani. 2017. Timeliness and Relevance of Financial Reporting in Nigerian Quote Firms. Management and Organizational Studies, Vol. 4 No. 2: 55-62.

Oussii, A. A. And N. B. Taktak. 2018. Audit Comittee Effectiveness and Financial Reporting Timeliness: The Case of Tunisian Listed Companies. African Journal of Economic and Management Studies, Vol. 9 No. 1: 34-55. 
Pradipta, D. M. dan B. Suryono. 2017. Analisis Faktor-Faktor Yang Mempengaruhi Ketepatan Waktu Pelaporan Keuangan. Jurnal Ilmu dan Riset Akuntansi, Vol. 6 No. 3: 1200-1216.

Putra, P. D. dan R. Thohiri. 2013. Analisis Faktor-Faktor yang Mempengaruhi Ketepatan Waktu Penyampaian Laporan Keuangan pada Perusahaan yang Listing di Bursa Efek Indonesia Periode 2008 - 2010. Jurnal Bina Akuntansi IBBI, Vol. 18 No. 1: 28-39.

Putra, I. G. A. P dan I. W. Ramantha. 2015. Pengaruh Profitabilitas, Umur Perusahaan, Kepemilikan Institusional, Komisaris Independen, dan Komite Audit pada Ketepatwaktuan Publikasi Laporan Keuangan Tahunan. E-Jurnal Akuntansi Universitas Udayana, Vol. 10 No. 1: 199-213.

Putri, B. P., Kennedy, dan Y. Anisma. 2015. Pengaruh Karakteristik Komite Audit, Fee Audit, Ukuran KAP, dan Internal Auditor Terhadap Ketepatan Waktu (Timeliness) Pelaporan Keuangan. Jurnal FEKON, Vol. 2 No. 2: 1-15.

Sanjaya, I. M. D. M dan N. G. P. Wirawati. 2016. Analisis Faktor-Faktor Yang Mempengaruhi Ketepatan Waktu Pelaporan Keuangan Pada Perusahaan Manufaktur Yang Terdaftar di BEI. E-Jurnal Akuntansi Universitas Udayana, Vol. 15 No. 1: 17-26.

Saputra, K. W. S. dan I. W. Ramantha. 2017. Pengaruh Profitabilitas dan Ukuran Perusahaan Terhadap Ketepatan Waktu Pelaporan Keuangan dengan Opini Audit Sebagai Pemoderasi. E-Jurnal Akuntansi Universitas Udayana, Vol. 20 No. 2: 1592-1620.

Siregar, S. V. dan S. Utama. 2005. Pengaruh Struktur Kepemilikan, Ukuran Perusahaan, dan Praktek Corporate Governance terhadap Pengelolaan Laba (Earnings Management). SNA VIII Solo.

Soares, M. dan M. N. Amin. 2016. Analisis Faktor-Faktor yang Mempengaruhi Timeliness of Financial Reporting dengan Reputasi Auditor sebagai Variabel Moderasi Atas Profitabilitas, Leverage, dan Umur Perusahaan (Studi Empiris Pada Perusahaan yang Terdaftar Di Bursa Efek Indonesia Periode 2010 - 2015). Jurnal Magister Akuntansi Trisakti, Vol. 3 No. 2: 121146.

Srimindarti, C. 2008. Ketepatan Waktu Pelaporan Keuangan. Fokus Ekonomi (FE), Vol. 7 No. 1: $14-21$.

Sufiyati. 2017. The Impact of Corporate Attributes on The Timeliness of Financial Reporting in Indonesia Stock Exchange. International Journal of Economic Perspectives, Vol. 11 No. 1: 1720-1730.

Turel, A. 2010. Timeliness of Financial Reporting in Emerging Capital Markets: Evidence from Turkey. Istanbul University Journal of The School of Business Administration, Vol. 39 No. 2: $227-240$.

Vuran, B. and B. Adiloglu. 2013. Is Timeliness of Corporate Financial Reporting Related to Accounting Variables? Evidence from Istanbul Stock Exchange. International Journal of Business and Social Science, Vol. 4 No. 6: 58-70.

Widyanjaya, B. R. 2014. Pengaruh Struktur Kepemilikan Perusahaan Terhadap Ketepatan Waktu Pelaporan Keuangan (Studi Empiris pada Perusahaan yang Terdaftar di Bursa Efek Indonesia Periode 2009 - 2012) (Tesis). Yogyakarta: Universitas Gadjah Mada.

Wirakusuma, M. G. dan P. M. Cindrawati. 2011. Pengaruh Profitabilitas, Solvabilitas, Reputasi Auditor, Ukuran Perusahaan, Kandungan Laba, dan Jenis Indrustri pada 
Ketidaktepatwaktuan Publikasi Laporan Keuangan di PT Bursa Efek Indonesia Periode 2007 - 2009. Jurnal Ilmiah Akuntansi dan Bisnis, Vol. 6 No. 2: 1-27.

Yadirichukwu, E. and A. Ebimobowei. 2013. Audit Committee and Timeliness of Financial Reports: Empirical Evidence from Nigeria. Journal of Economics and Sustainable Development, Vol. 4 No. 20: 14-25. 